\title{
Mate selection in captive-breeding rockfishes Sebastes spp.: inference from parentage analysis and the major histocompatibility complex (MHC)
}

\author{
M. L. Johansson ${ }^{1,4, *}$, K. Clifford ${ }^{2}$, B. Fodness ${ }^{2}$, N. A. Vazquez ${ }^{3}$, M. A. Banks ${ }^{1}$ \\ ${ }^{1}$ Coastal Oregon Marine Experiment Station, Hatfield Marine Science Center, Oregon State University, Newport, \\ Oregon 97365, USA \\ ${ }^{2}$ Oregon Coast Aquarium, Newport, Oregon 97365, USA \\ ${ }^{3}$ Department of Environmental Science, Technology, and Policy, California State University Monterey Bay, Seaside, \\ California 93955, USA \\ ${ }^{4}$ Present address: Department of Biological Sciences, University of Wisconsin-Milwaukee, Milwaukee, \\ Wisconsin 53201, USA
}

\begin{abstract}
Rockfish species of the genus Sebastes are notable for being numerous and diverse. Rockfishes are unusual among fish because they fertilize their eggs internally and release live, swimming larvae. They undergo complex courting behaviors, which may allow females to be selective about their mates. The major histocompatibility complex (MHC) is implicated as having an important influence on mate selection in other fishes, especially in sticklebacks and salmonids. Research suggests that females choose mates that optimize the MHC genotypes of their offspring. Previous research on rockfishes indicates that multiple functional MHC sequences may be found in each species, and that multiple mating is common in the genus, possibly as a bet-hedging strategy against uncertain or incomplete mate-selection information. In this project, we characterized the MHC genotypes of copper ( $S$. caurinus) and quillback $(S$. maliger) rockfish parents, assessed parentage of 14 larval broods, and assessed the MHC genotypes of the parents to determine if MHC-mediated mate choice was occurring. As in previous studies, we found that rockfishes possess multiple, highly variable MHC genes, and that females may mate with multiple males. We also found evidence of female preference for particular males. However, we found no strong evidence of selection based on MHC genotype. Females were not consistently selective based on relatedness, allele count, proportion of shared alleles, or minimum, mean, or maximum DNA or amino acid genetic distance. Instead, it appears that females were selective based on other measures of mate quality not considered in this study, with some hedging of bets through multiple mating also occurring.
\end{abstract}

KEY WORDS: Major histocompatibility complex $\cdot$ MHC $\cdot$ Mate choice $\cdot$ Balancing selection · Mating system $\cdot$ Multiple paternity $\cdot$ Hybridization

\section{INTRODUCTION}

The genus Sebastes (the rockfishes) is notable for being speciose (approximately 110 species worldwide) and extremely diverse. Members of the genus are found in a variety of habitat types, from the inter- tidal zone to depths over $1000 \mathrm{~m}$ (Love et al. 2002). Morphology varies widely, and is correlated with life history and ecological role. Types range from streamlined, semi-pelagic species such as the bocaccio $S$. paucispinis, to deep-bodied, spiny, benthic forms, such as the cowcod $S$. levis. A full range of interme- 
diate morphologies also exists in the genus (Love et al. 2002). Rockfishes are long-lived, with some species, such as the rougheye rockfish $S$. aleutianus (205 yr) and shortraker rockfish S. borealis (156 yr) estimated to be among the longest-lived fishes in the world (Love et al. 2002). The group is particularly distinguished by the evolution of internal fertilization (Wourms 1991), which may afford them a greater ability to be selective about their mates than is typical of marine fishes.

In contrast to the majority of teleost fishes, rockfishes fertilize their eggs internally and release live, swimming larvae. Larvae are released at the pre-flexion yolk-sac stage, which allows them to avoid the high mortality associated with the egg and early larval stages for a relatively small maternal investment (Boehlert \& Yoklavich 1984). Rockfishes are highly fecund, with broods containing thousands to millions of larvae per female (Love et al. 2002). In the unstable environmental conditions of the northeast Pacific, larval survival and recruitment are highly variable from year to year, and strong recruitment may occur only once in decades (Tolimieri \& Levin 2005). Long lifespan coupled with high fecundity thus functions as a bet-hedging strategy to ensure population persistence between rare recruitment events in marine fishes such as rockfishes (Winemiller \& Rose 1992).

Evidence suggests that rockfishes undergo complex courting behaviors, which may include pheromones and sight or sound cues, before mating can take place (Hallacher 1974, Helvey 1982, Shinomiya \& Ezaki 1991, Gingras et al. 1998). Ultimately, the decision whether or not to mate appears to lie with the female (Hyde et al. 2008). Multiple mating, with up to 4 different fathers, has been demonstrated in 13 different rockfish species to date, and may be a common bethedging strategy in the genus when mate selection criteria are uncertain or incomplete (Yasui 2001, Hyde et al. 2008, Sogard et al. 2008, Van Doornik et al. 2008, Blanco Gonzalez et al. 2009). As consequences of selective mate choice by females and multiple paternity, a population of organisms that experiences sweepstakes recruitment, such as rockfishes, may experience enhanced genetic diversity and avoid the loss of rare alleles, may see diminished impacts of inbreeding depression, and may benefit from increased effective population size (Hedgecock 1994). Although chance may play the primary role in reproductive success for bet-hedging marine fishes, such as rockfishes (Winemiller \& Rose 1992), another potential benefit of mate choice and multiple paternity may be improved pathogen or parasite resistance through optimization of major histocompatibility complex (MHC) genotype.
The MHC is a highly polymorphic multigene family involved in self-nonself recognition in the immune system of vertebrates. MHC genes encode receptors that bind fragments of local and foreign peptides, then present the combined fragments to T-cells, which may initiate a series of immune responses (Ploegh \& Watts 1998). The amino acid (AA) sequence of the MHC protein determines antigen binding, and thus, which foreign peptides can be recognized (Brown et al. 1988). Therefore, greater MHC diversity would be expected to result in greater sensitivity to pathogens and a more effective immune response (Doherty \& Zinkernagel 1975). Because self-reactivity can lower the number of T-cells in species that express several MHC loci, an intermediate number of alleles may result in better pathogen recognition in these cases (Woelfing et al. 2009). Given the high polymorphism and potential benefits associated with MHC-based mate preference, 2 main hypotheses have been proposed: (1) MHC genotypes could function to discriminate close kin, and might help females to avoid inbreeding (Penn \& Potts 1999, Landry et al. 2001), or (2) negative assortative mating based on MHC genotype might improve the pathogen resistance of offspring (Doherty \& Zinkernagel 1975, Landry et al. 2001). Mate selection based on MHC genotype has been demonstrated in several fish species to date, including three-spined sticklebacks Gasterosteus aculeatus (Reusch et al. 2001, Aeschlimann et al. 2003, Milinski et al. 2005, Eizaguirre et al. 2009, Kalbe et al. 2009, Lenz et al. 2009), a variety of salmonids (Atlantic salmon Salmo salar: Landry et al. 2001, Consuegra \& de Leaniz 2008; brown trout Salmo trutta: Forsberg et al. 2007; Chinook salmon Oncorhynchus tshawytscha: Neff et al. 2008, Garner et al. 2010), and other freshwater fish species (e.g. rose bitterling Rhodeus occelatus: Casalini et al. 2009). This research suggests that MHC genes do influence mate choice decisions in fish, that both good genes (i.e. specific alleles that confer improved pathogen resistance) and overall MHC diversity may be considered by females, and that mating decisions may be complicated by other factors, such as body size and coloration or aggression between individuals (Landry et al. 2001, Reusch et al. 2001, Consuegra \& de Leaniz 2008, Neff et al. 2008, Eizaguirre et al. 2009, Kalbe et al. 2009, Garner et al. 2010). However, there are very few studies on MHC-based mate selection in marine fishes. One reason for this may be the difficulty of performing laboratory-based experimental research on large, long-lived marine fishes. Another reason may be that marine fishes are much less likely to encounter close 
kin, which would make the hypothesis that MHCbased mate selection partially functions to avoid inbreeding much less applicable (Landry et al. 2001). However, since marine fishes are exposed to numerous parasite threats, the potential improvement in immunocompetence associated with mate selection based on MHC genotype should apply equally to marine and freshwater fishes (Penn et al. 2002).

Copper (Sebastes caurinus) and quillback (S. maliger) rockfishes were chosen as model organisms to study MHC diversity and mate selection in nearshore rockfishes. The copper rockfish is found from the northern Gulf of Alaska to central Baja California, in waters from the subtidal zone to depths of $\sim 180 \mathrm{~m}$. The quillback rockfish ranges from the Gulf of Alaska to the northern California Bight, and is found from subtidal depths to $\sim 275 \mathrm{~m}$ (Love et al. 2002). Both species prefer areas of high- to medium-relief rocks, although they may also be found over lowrelief rock habitat. Both are long-lived, with coppers aged to $50 \mathrm{yr}$, and quillbacks aged to at least $95 \mathrm{yr}$ (Love et al. 2002). Likewise, both mature around $7 \mathrm{yr}$ (Lea et al. 1999). Larval release occurs between January and June in copper rockfish, and between March and June in quillback rockfish (Love et al. 2002). Both species probably only produce a single brood annually (Moser 1967). Copper and quillback rockfishes have been shown to hybridize in nature (Seeb 1998). An MHC class II B genotype has been described for a single copper rockfish (Aguilar \& Garza 2005), but no data have yet been published on quillback rockfish. No research has been published on multiple paternity or mate selection in either species.

Our goals in this study were threefold. First, we characterized MHC diversity in captive-breeding populations consisting of 69 copper and 89 quillback rockfishes at the Oregon Coast Aquarium (Newport, OR). Then, we genotyped larvae of known mothers to assess parentage, including the prevalence of multiple paternity in these 2 previously unexamined species. Finally, we related the MHC genotypes of the parents of realized matings to the suite of possible matings to draw inferences about the role of MHC genotype in mate choice in rockfishes.

\section{MATERIALS AND METHODS}

\section{Adult tissue collections}

Copper and quillback rockfishes were collected as newly settled juveniles or as adults from the
Pacific Ocean near Newport, Oregon to populate the Passages of the Deep section of the Oregon Coast Aquarium between 1997 and 1999 (J. Burke pers. comm.). In September and October of 2009, all the adult copper and quillback rockfishes were collected from the Orford Reef display tank in the Passages of the Deep section of the Oregon Coast Aquarium by divers using hand nets. Fish were placed into an adjacent medical isolation tank until all individuals had been captured. Fin-clip tissue samples were collected from each individual and stored in $95 \%$ ethanol for DNA analysis, and each fish was PIT-tagged for future identification before release back into the display tank.

\section{Larvae collections}

In 2009 and 2010, gravid female copper and quillback rockfishes were collected by SCUBA divers using hand nets from the Orford Reef tank, identified based on their PIT-tag number, and individually placed into $757 \mathrm{l}$ plastic barrels with isolated inflow and filtered outflow until they released their larvae. Larval samples were collected by hand with dip nets and preserved in $50 \mathrm{ml}$ Falcon tubes with $95 \%$ ethanol. A total of 4 broods were collected and genotyped in 2009 (additional broods were collected but failed to yield genotypes), and a total of 10 broods were collected and genotyped in 2010 .

\section{MHC genotyping}

Total genomic DNA was extracted from adult fin-clip tissue samples using a standard glass-fiber plate protocol (Ivanova et al. 2006). Polymerase chain reaction (PCR), with primers XIS and MRS (Cohen 2002), was used to amplify the majority of exon 2 of the MHC B1 unit, along with the preceding intron and a segment of the leader peptide for all adult samples. PCR reactions were performed with GoTaq Flexi polymerase (Promega) and optimized for high fidelity. PCR cycling conditions were as follows: initial denaturation at $95^{\circ} \mathrm{C}$ for $2 \mathrm{~min}$, then 35 cycles of $95^{\circ} \mathrm{C}$ for $30 \mathrm{~s}, 50^{\circ} \mathrm{C}$ for $30 \mathrm{~s}$, and $72^{\circ} \mathrm{C}$ for $1 \mathrm{~min}$, followed by a final extension at $72^{\circ} \mathrm{C}$ for $5 \mathrm{~min}$. These PCR products were cloned using the TOPO TA cloning kit (Invitrogen), and 12 colonies were sequenced per adult sample. Clones were sequenced on an ABI 3730XL (Applied Biosystems) capillary sequencer using 
M13 forward and reverse primers. All sequences were aligned and edited in Sequencher v4.7 (Gene Codes), and trimmed to include only exon sequences (based on sequences from Aguilar \& Garza 2005) for analysis. All exon sequences have been deposited in Genbank (Accession nos. JQ620251-JQ621832). Only unique exon sequences were used in MHC diversity analyses. Although the total number of MHC genes in rockfishes is unknown, we hereafter refer to distinct sequences as alleles. Synonymous $\left(d_{\mathrm{s}}\right)$ and non-synonymous $\left(d_{\mathrm{n}}\right)$ substitution rates were calculated for the complete exon, and for putative antigen binding site (ABS) and non-ABS codons (inferred from the human HLA-DRB1 locus; Brown et al. 1993; and following Aguilar \& Garza 2005 and Cohen 2002) using DnaSP v5.0 (Librado \& Rozas 2009). Significance of $d_{\mathrm{n}}: d_{\mathrm{s}}$ ratios was tested using a paired Student's $t$-test in S-Plus (Insightful).

\section{Parentage analysis}

Genomic DNA was extracted from adult fin-clip tissue samples or whole larvae using a standard glass-fiber-plate protocol (Ivanova et al. 2006). For all adults, 22 previously published microsatellite markers (Table 1; Roques et al. 1999, Wimberger et al. 1999, Miller et al. 2000, Gomez-Uchida et al. 2003, Westerman et al. 2005) were genotyped and tested for utility in parentage analysis. Locus-bylocus deviations from Hardy-Weinberg equilibrium and inbreeding coefficients were assessed using Genetix v4.05.2 (Table 1; Belkhir et al. 2004). Larval genotypes utilizing 6 markers (Spi4, Spi6, Spi10 [Gomez-Uchida et al. 2003]; Sma3, Sma10, Sma11 [Wimberger et al. 1999]) were adequate to unambiguously identify parents. Microsatellite markers were PCR amplified with fluorescentlylabeled forward primers (MWG Biotech). PCR conditions were as follows: initial denaturation at $94^{\circ} \mathrm{C}$ for $2 \mathrm{~min}$, then $25 \mathrm{cycles}$ of $94^{\circ} \mathrm{C}$ for $1 \mathrm{~min}$, $45-62^{\circ} \mathrm{C}$ for $30 \mathrm{~s}$, and $72^{\circ} \mathrm{C}$ for $30 \mathrm{~s}$, followed by a final extension at $72^{\circ} \mathrm{C}$ for $10 \mathrm{~min}$. PCR products were visualized alongside internal molecular weight standards using an ABI 3730XL DNA analyzer and sized using Genemapper (ABI) software. Parentage was assessed using GERUD2.0 (Jones 2005) with known maternal genotypes. Putative paternal genotypes reconstructed from larval genotypes in GERUD2.0 were matched to the data set of true parental genotypes to identify actual fathers.

\section{Mate selection}

To assess whether females mated non-randomly with the available males in our captive population, we conducted hypothesis tests on 5 different parameters. In each case, we calculated the parameter for all possible pairs in the population using custom scripts in R (R Development Core Team 2011), and calculated critical values (2.5 and $97.5 \%$ quantiles for 2 sided tests, 95\% quantile for 1-sided tests) for the population. Then, we calculated each parameter for all the pairings we observed in our matings. We also calculated the mean value for each parameter for the following 5 groupings of our observed matings: all broods, Male 2592 alone, Male 2653 alone, all broods excluding Male 2592, and all broods excluding Males 2592 and 2653. We tested the hypothesis that females choose mates based on their level of relatedness, by calculating maximum-likelihood estimates of relatedness $(r)$ in ML-Relate (Kalinowski et al. 2006) using all 22 genotyped microsatellite markers. Because the level of pairwise relatedness was low on average in the population, we tested the hypothesis that females mated with more closely related males than if they had been choosing randomly (1-tailed test). We also performed several hypothesis tests to assess the association between MHC genotype and mate choice in rockfishes.

In all MHC tests we assumed that MHC genotypes were unbiased and were a random sampling of the loci present in the individual, since the primers used (XIS and MRS; Cohen 2002) are highly degenerate. To test whether females choose mates based on differences in allele counts, we calculated pairwise absolute differences between the number of distinct MHC alleles found in the mother versus number of distinct alleles found in the father. The hypothesis being tested here was that females chose males with significantly greater or fewer distinct alleles (2-tailed test). To test the hypothesis that females select mates based on shared alleles, we calculated the proportion of shared MHC alleles (Wetton et al. 1987). The proportion of shared alleles (D) was calculated as $\mathrm{D}=$ $2 F_{\mathrm{ab}} /\left(F_{\mathrm{a}}+F_{\mathrm{b}}\right)$, where $F_{\mathrm{ab}}$ is the number of alleles shared by the individuals in the pair, and $F_{\mathrm{a}}$ and $F_{\mathrm{b}}$ are the numbers of alleles found in each individual. The hypothesis here was that mated pairs share significantly more alleles than random pairs drawn from the population (1-tailed test). To test the hypothesis that females choose mates based on genetic distances between their own and potential mates' alleles, we calculated the mean, minimum, and maximum DNA distance and AA distance between all 
Table 1. Sebastes caurinus (copper rockfish) and $S$. maliger (quillback rockfish). Genotyping primers, locus-by-locus number of alleles, expected $\left(H_{\mathrm{e}}\right)$ and observed $\left(H_{\mathrm{o}}\right)$ heterozygosities with significance $(\mathrm{p})$, and inbreeding coefficient $\left(F_{\mathrm{IS}}\right)$ with significance (p), characterized for all possible parents in Orford Reef display tank, Oregon Coast Aquarium. Markers used in parentage analysis are highlighted in grey. Temperature profile: $94^{\circ} \mathrm{C} / 2 \mathrm{~min}, 25 \times\left(94^{\circ} \mathrm{C} / 1 \mathrm{~min}, \mathrm{anneal}_{/} 30 \mathrm{~s}, 72^{\circ} \mathrm{C} / 10 \mathrm{~s}\right)$, $72^{\circ} \mathrm{C} / 10 \mathrm{~min}, 10^{\circ} \mathrm{C}$ hold

\begin{tabular}{|c|c|c|c|c|c|c|c|c|c|}
\hline Locus & Species & $\begin{array}{c}\text { Number } \\
\text { of } \\
\text { alleles }\end{array}$ & $H_{\mathrm{e}}$ & $H_{\mathrm{o}}$ & $\mathrm{p}$ & $F_{\mathrm{IS}}$ & $\mathrm{p}$ & $\begin{array}{c}\text { Annealing } \\
\text { temperature } \\
\left({ }^{\circ} \mathrm{C}\right)\end{array}$ & Source \\
\hline \multirow[t]{2}{*}{ Spi4 } & Copper & 15 & 0.88 & 0.84 & 0.342 & 0.042 & 0.187 & 58 & Gomez-Uchida et al. (2003 \\
\hline & Quillback & 16 & 0.88 & 0.88 & 0.739 & 0.010 & 0.472 & & \\
\hline \multirow[t]{2}{*}{ Spi6 } & Copper & 20 & 0.90 & 0.88 & 0.340 & 0.022 & 0.321 & 58 & \\
\hline & Quillback & 19 & 0.88 & 0.88 & 0.359 & 0.007 & 0.481 & & \\
\hline \multirow[t]{2}{*}{ Spi10 } & Copper & 5 & 0.64 & 0.75 & 0.980 & -0.178 & 0.992 & 58 & \\
\hline & Quillback & 4 & 0.61 & 0.60 & 0.214 & 0.020 & 0.437 & & \\
\hline \multirow[t]{2}{*}{ Spi12 } & Copper & 4 & 0.40 & 0.39 & 0.137 & 0.027 & 0.444 & 58 & \\
\hline & Quillback & 7 & 0.43 & 0.36 & 0.002 & 0.156 & 0.031 & & \\
\hline \multirow{2}{*}{ Spi18 } & Copper & 24 & 0.89 & 0.89 & 0.044 & 0.000 & 0.565 & 58 & \\
\hline & Quillback & 21 & 0.87 & 0.84 & 0.005 & 0.034 & 0.217 & & \\
\hline \multirow[t]{2}{*}{ Sma1 } & Copper & 13 & 0.80 & 0.87 & 0.956 & -0.093 & 0.988 & 48 & Wimberger et al. (1999) \\
\hline & Quillback & 12 & 0.67 & 0.63 & 0.077 & 0.061 & 0.171 & & \\
\hline \multirow{2}{*}{ Sma2 } & Copper & 6 & 0.32 & 0.31 & 0.021 & 0.012 & 0.510 & 58 & \\
\hline & Quillback & 5 & 0.47 & 0.38 & 0.047 & 0.182 & 0.030 & & \\
\hline \multirow[t]{2}{*}{ Sma3 } & Copper & 7 & 0.58 & 0.61 & 0.728 & -0.055 & 0.790 & 58 & \\
\hline & Quillback & 5 & 0.72 & 0.76 & 0.916 & -0.067 & 0.899 & & \\
\hline \multirow[t]{2}{*}{ Sma4 } & Copper & 7 & 0.60 & 0.54 & 0.017 & 0.109 & 0.129 & 58 & \\
\hline & Quillback & 6 & 0.71 & 0.66 & 0.001 & 0.078 & 0.135 & & \\
\hline \multirow{2}{*}{ Sma5 } & Copper & 3 & 0.12 & 0.10 & 0.004 & 0.186 & 0.149 & 58 & \\
\hline & Quillback & 4 & 0.44 & 0.46 & 0.615 & -0.045 & 0.710 & & \\
\hline \multirow[t]{2}{*}{ Sma10 } & Copper & 16 & 0.70 & 0.64 & 0.153 & 0.084 & 0.123 & 58 & \\
\hline & Quillback & 15 & 0.81 & 0.72 & 0.001 & 0.116 & 0.013 & & \\
\hline \multirow[t]{2}{*}{ Sma11 } & Copper & 6 & 0.66 & 0.73 & 0.856 & -0.107 & 0.936 & 58 & \\
\hline & Quillback & 10 & 0.62 & 0.55 & 0.057 & 0.112 & 0.039 & & \\
\hline \multirow[t]{2}{*}{ Seb9 } & Copper & 5 & 0.59 & 0.66 & 0.269 & -0.117 & 0.900 & 62 & Roques et al. (1999) \\
\hline & Quillback & 5 & 0.67 & 0.66 & 0.280 & 0.017 & 0.443 & & \\
\hline \multirow[t]{2}{*}{ Sal1 } & Copper & 11 & 0.81 & 0.71 & 0.069 & 0.122 & 0.033 & 45 & Miller et al. (2000) \\
\hline & Quillback & 8 & 0.77 & 0.72 & 0.125 & 0.076 & 0.115 & & \\
\hline \multirow[t]{2}{*}{ Sal2 } & Copper & 6 & 0.61 & 0.64 & 0.586 & -0.052 & 0.794 & 48 & \\
\hline & Quillback & 9 & 0.72 & 0.67 & 0.037 & 0.065 & 0.143 & & \\
\hline \multirow[t]{2}{*}{ Sal3 } & Copper & 10 & 0.68 & 0.64 & 0.241 & 0.054 & 0.255 & 48 & \\
\hline & Quillback & 8 & 0.63 & 0.43 & $<0.001$ & 0.324 & $<0.001$ & & \\
\hline \multirow[t]{2}{*}{ Sal4 } & Copper & 10 & 0.82 & 0.81 & 0.085 & 0.011 & 0.475 & 52 & \\
\hline & Quillback & 8 & 0.79 & 0.77 & 0.468 & 0.022 & 0.401 & & \\
\hline \multirow{2}{*}{ Sra7-7 } & Copper & 11 & 0.70 & 0.77 & 0.865 & -0.107 & 0.959 & 57 & Westerman et al. (2005) \\
\hline & Quillback & 13 & 0.77 & 0.81 & 0.552 & -0.045 & 0.834 & & \\
\hline \multirow[t]{2}{*}{ Sra7-25 } & Copper & 13 & 0.83 & 0.83 & 0.507 & 0.001 & 0.548 & 57 & \\
\hline & Quillback & 11 & 0.81 & 0.73 & 0.018 & 0.098 & 0.040 & & \\
\hline \multirow[t]{2}{*}{ Sra11-103 } & Copper & 3 & 0.43 & 0.40 & 0.277 & 0.068 & 0.338 & 57 & \\
\hline & Quillback & 3 & 0.28 & 0.25 & 0.181 & 0.129 & 0.169 & & \\
\hline \multirow[t]{2}{*}{ Sra15-8 } & Copper & 12 & 0.81 & 0.79 & 0.162 & 0.033 & 0.311 & 52 & \\
\hline & Quillback & 7 & 0.80 & 0.79 & 0.364 & 0.013 & 0.476 & & \\
\hline \multirow{2}{*}{ Sra16-5 } & Copper & 30 & 0.95 & 0.97 & 0.666 & -0.020 & 0.858 & 52 & \\
\hline & Quillback & 22 & 0.86 & 0.79 & 0.098 & 0.081 & 0.030 & & \\
\hline
\end{tabular}

possible pairings in our population, and between our actual matings. DNA distances were calculated using an F84 (Felsenstein 1984) substitution model in the DNADIST module of Phylip v3.67 (Felsenstein 1989). Amino acid distances were calculated using the Day- hoff PAM substitution matrix (Dayhoff 1979) as implemented in the PROTDIST module of Phylip v3.67 (Felsenstein 1989). For mean and maximum distances, we tested the hypothesis that our realized matings had significantly higher or lower distances 
than random pairs drawn from the population (2tailed test). For the minimum distance, we tested the hypothesis that actual matings had significantly higher distances than random population draws (1-tailed test).

\section{RESULTS}

\section{MHC genotyping}

Sequences between 400 and 800 base pairs (bp) in length were recovered from both study species. Genbank nucleotide BLAST (NCBI) searches utilizing these sequences as the query invariably returned previously published (Aguilar \& Garza 2005) Sebastes MHC sequences as the highest-likelihood match. In accordance with the findings of Aguilar \& Garza (2005), sequences were composed of a long intron, containing a variably-repeated minisatellite sequence with no species-specific pattern, and a 255 bp exon sequence. We found between 2 and 9 unique sequences per individual copper rockfish, and between 2 and 10 sequences in quillback rockfish. The mean \pm SD number of unique sequences per individual (standardized to sequences per 10 clones) was $5.31 \pm 1.62$ for copper rockfish and $5.58 \pm 1.63$ for quillback rockfish (Fig. 1). We identified a total of 166 alleles in 69 copper rockfish and 315 alleles in 89 quillback rockfish. Forty-one sequences were found

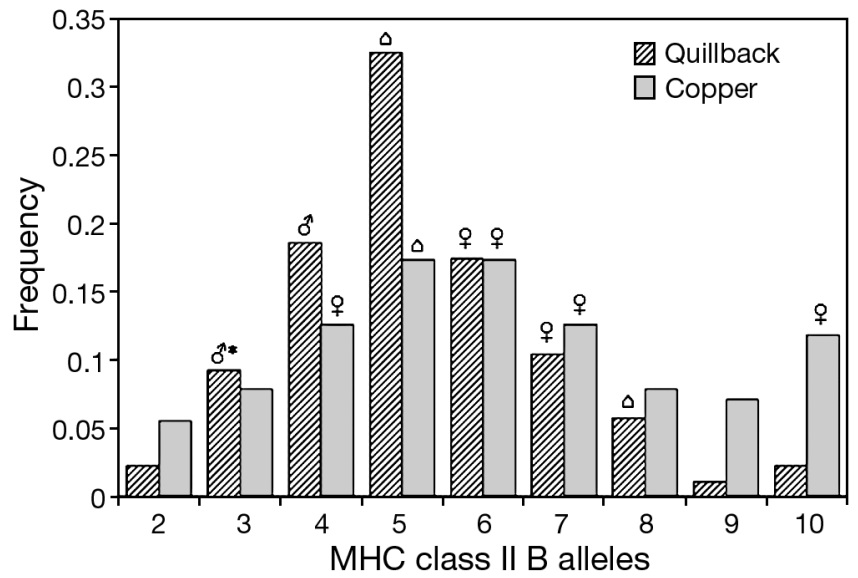

Fig. 1. Sebastes caurinus (copper rockfish) and S. maliger (quillback rockfish). Frequency distribution of the number of major histocompatibility complex (MHC) class II B alleles (exon 2 sequences) in 69 adult copper (striped bars) and 87 quillback (grey bars) rockfishes from the Oregon Coast Aquarium. Mean \pm SD number of MHC alleles per 10 clones sequenced was $5.31 \pm 1.62$ for copper rockfish and 5.58 \pm 1.63 for quillback rockfish. (o) Presence of a female parent, $\left(\sigma^{7}\right)$ presence of a male parent, and ( $\Delta$ ) both parents in the category; $\left(0^{7 *}\right)$ dominant male (ID no. 2592) in our broods

in both species. Allele sequences varied widely, with genetic distances (General time reversible + Invariant sites + Gamma distributed model) between sequences ranging from a minimum of 0.00395 to a maximum of 0.38749 across both species. The ratio of

Table 2. Sebastes caurinus (copper rockfish) and S. maliger (quillback rockfish). Brood, mother's ID, mother's species, number of larvae successfully genotyped, number of unique paternal alleles detected at each locus, identified sires, and the number of larvae fathered by each sire. ${ }^{*}$ indicates hybridization

\begin{tabular}{|c|c|c|c|c|c|c|c|c|c|c|}
\hline Brood & $\begin{array}{l}\text { Mother's } \\
\text { ID }\end{array}$ & Species & $\begin{array}{l}\text { No. of } \\
\text { larvae }\end{array}$ & Spi4 & Spi6 & Spi10 & Sma3 & Sma10 & Sma11 & $\begin{array}{l}\text { ID of sires } \\
\text { (number of larvae) }\end{array}$ \\
\hline 1 & $\begin{array}{l}2501 \\
(2009 \text { brood) }\end{array}$ & Copper & 93 & 2 & 1 & 1 & 0 & 0 & 1 & $2592^{*}(92), 2653^{*}(1)$ \\
\hline 2 & $\begin{array}{l}2501 \\
(2010 \text { brood) }\end{array}$ & Copper & 91 & 2 & 1 & 1 & 0 & 0 & 1 & $2592^{*}(91)$ \\
\hline 3 & 2502 & Quillback & 94 & 2 & 1 & 0 & 1 & 0 & 2 & $2592(94)$ \\
\hline 4 & $\begin{array}{l}2504 \\
(2009 \text { brood })\end{array}$ & Copper & 92 & 2 & 3 & 2 & 0 & 2 & 2 & $2575(87), 2529^{*}(5)$ \\
\hline 5 & $\begin{array}{l}2504 \\
(2010 \text { brood })\end{array}$ & Copper & 93 & 2 & 2 & 0 & 1 & 0 & 1 & $2592^{*}(93)$ \\
\hline 6 & 2506 & Quillback & 87 & 2 & 1 & 0 & 1 & 1 & 0 & $2523(87)$ \\
\hline 7 & 2566 & Quillback & 94 & 2 & 2 & 0 & 1 & 2 & 0 & $2585(94)$ \\
\hline 8 & 2571 & Copper & 93 & 1 & 1 & 1 & 0 & 1 & 0 & $2653^{*}(93)$ \\
\hline 9 & 2574 & Copper & 94 & 4 & 2 & 1 & 2 & 1 & 2 & $2638(76), 2592^{*}(18)$ \\
\hline 10 & 2590 & Copper & 183 & 1 & 1 & 1 & 0 & 1 & 1 & $2653^{*}(183)$ \\
\hline 11 & 2598 & Copper & 86 & 2 & 1 & 0 & 1 & 0 & 2 & $2592^{*}(86)$ \\
\hline 12 & 2608 & Quillback & 93 & 1 & 2 & 0 & 1 & 0 & 1 & $2592(93)$ \\
\hline 13 & 2628 & Copper & 93 & 2 & 1 & 1 & 0 & 0 & 1 & $2582(93)$ \\
\hline 14 & 2670 & Copper & 93 & 1 & 2 & 0 & 1 & 0 & 1 & $2592^{*}(93)$ \\
\hline
\end{tabular}


Table 3. Sebastes caurinus (copper rockfish) and $S$. maliger (quillback rockfish). Mean ( \pm SD) non-synonymous $\left(d_{n}\right)$ and synonymous $\left(d_{\mathrm{s}}\right)$ substitution rates for comparisons within and between species, $d_{\mathrm{n}}: d_{\mathrm{s}}$ ratios, and results of paired Student's $t$-tests testing the hypothesis that $d_{\mathrm{n}}=d_{\mathrm{s}}$. ABS = antigen binding site

\begin{tabular}{|c|c|c|c|c|c|c|c|}
\hline Species & Gene region & $d_{\mathrm{n}}$ & $d_{\mathrm{s}}$ & $d_{\mathrm{n}}: d_{\mathrm{s}}$ & $t$ & df & $\mathrm{p}$ \\
\hline \multirow[t]{3}{*}{ Both } & ABS & $0.348( \pm 0.114)$ & $0.146( \pm 0.100)$ & 2.381 & 926.0 & \multirow[t]{3}{*}{144452} & $<0.001$ \\
\hline & Non-ABS & $0.156( \pm 0.050)$ & $0.078( \pm 0.049)$ & 2.008 & 635.1 & & $<0.001$ \\
\hline & Overall & $0.209( \pm 0.060)$ & $0.096( \pm 0.052)$ & 2.174 & 705.6 & & $<0.001$ \\
\hline \multirow[t]{3}{*}{ Copper } & ABS & $0.351( \pm 0.116)$ & $0.153( \pm 0.106)$ & 2.289 & 278.9 & \multirow[t]{3}{*}{29645} & $<0.001$ \\
\hline & Non-ABS & $0.153( \pm 0.052)$ & $0.078( \pm 0.051)$ & 1.971 & 299.9 & & $<0.001$ \\
\hline & Overall & $0.208( \pm 0.062)$ & $0.098( \pm 0.055)$ & 2.120 & 392.0 & & $<0.001$ \\
\hline \multirow[t]{3}{*}{ Quillback } & ABS & $0.347( \pm 0.116)$ & $0.143( \pm 0.096)$ & 2.427 & 381.8 & \multirow[t]{3}{*}{50085} & $<0.001$ \\
\hline & Non-ABS & $0.159( \pm 0.052)$ & $0.078( \pm 0.049)$ & 2.038 & 434.1 & & $<0.001$ \\
\hline & Overall & $0.211( \pm 0.062)$ & $0.096( \pm 0.051)$ & 2.204 & 561.9 & & $<0.001$ \\
\hline
\end{tabular}

non-synonymous $\left(d_{\mathrm{n}}\right)$ to synonymous $\left(d_{\mathrm{s}}\right)$ substitution rates was significantly $>1$ in all comparisons (Table 2 ). This higher rate of non-synonymous versus synonymous substitutions was found in both species (combined, and considered separately), and irrespective of whether all codons were considered; solely putative ABS codons, or solely non-ABS codons.

\section{Parentage analysis}

We identified paternity of a total of 1379 larvae in 14 broods (Table 3). In 13 of 14 cases, GERUD2.0 reconstructed a single putative paternal genotype. In one case (Mother 2501, 2009 brood), GERUD2.0 returned 40 potential paternal genotype pairs. In this case, only 1 of the top 5 most likely paternal genotypes matched actual fathers in the parental data set. Twelve different mothers produced larvae, and 8 different fathers were matched to GERUD reconstructions in the sample set. Two mothers produced larvae in both 2009 and 2010. Three broods showed evidence of multiple paternity (2 sires), although the contribution of the second father was always a small fraction of the total (no more than $20 \%$ ). One sire, 2592, was involved in producing 8 of the 14 broods in the sample set. This individual, a quillback rockfish, mated with females of both species and produced viable larvae with both (data not shown). Other hybrid matings were also observed in the sample set.

\section{Mate selection}

Only a single observed mate pair (out of 17 mated pairs in 14 broods) had a relatedness value that exceeded the $95 \%$ critical value (Table 4 ). None of the group means exceeded the $95 \%$ value for relatedness. Likewise, no individual or mean absolute allele number difference was greater than the $95 \%$ critical value. Three mate pairs shared a significantly greater proportion of their alleles than expected due to chance. Considering DNA distances, 3 pairs had mean values that fell below the $2.5 \%$ critical value and 1 pair had a mean value that exceeded the $97.5 \%$ value. Two pairs had maximum distance values that fell below the $2.5 \%$ critical value. No mate pairs had maximum distance values that exceeded the $97.5 \%$ critical value and none of the 5 group means diverged significantly from the population values for mean or maximum DNA distance. Four pairs had significantly greater minimum DNA distances than would be expected due to chance, but none of the minimum DNA distance group mean values were significantly different from the population mean. Amino acid distances showed the same pattern as DNA distances. Three pairs had significantly smaller mean AA distances than expected by chance, while 1 pair had a significantly larger mean distance. Two pairs had significantly smaller maximum AA distances. Finally, 2 pairs had significantly greater minimum AA distances than expected by chance, and a further 2 pairs were nearly significant (these near-significant pairs were significant in the DNA analysis). None of the AA distance group means diverged significantly from the underlying population.

\section{DISCUSSION}

\section{MHC genotyping}

Both copper and quillback rockfishes show evidence of multiple MHC class II B genes. Aguilar \& 


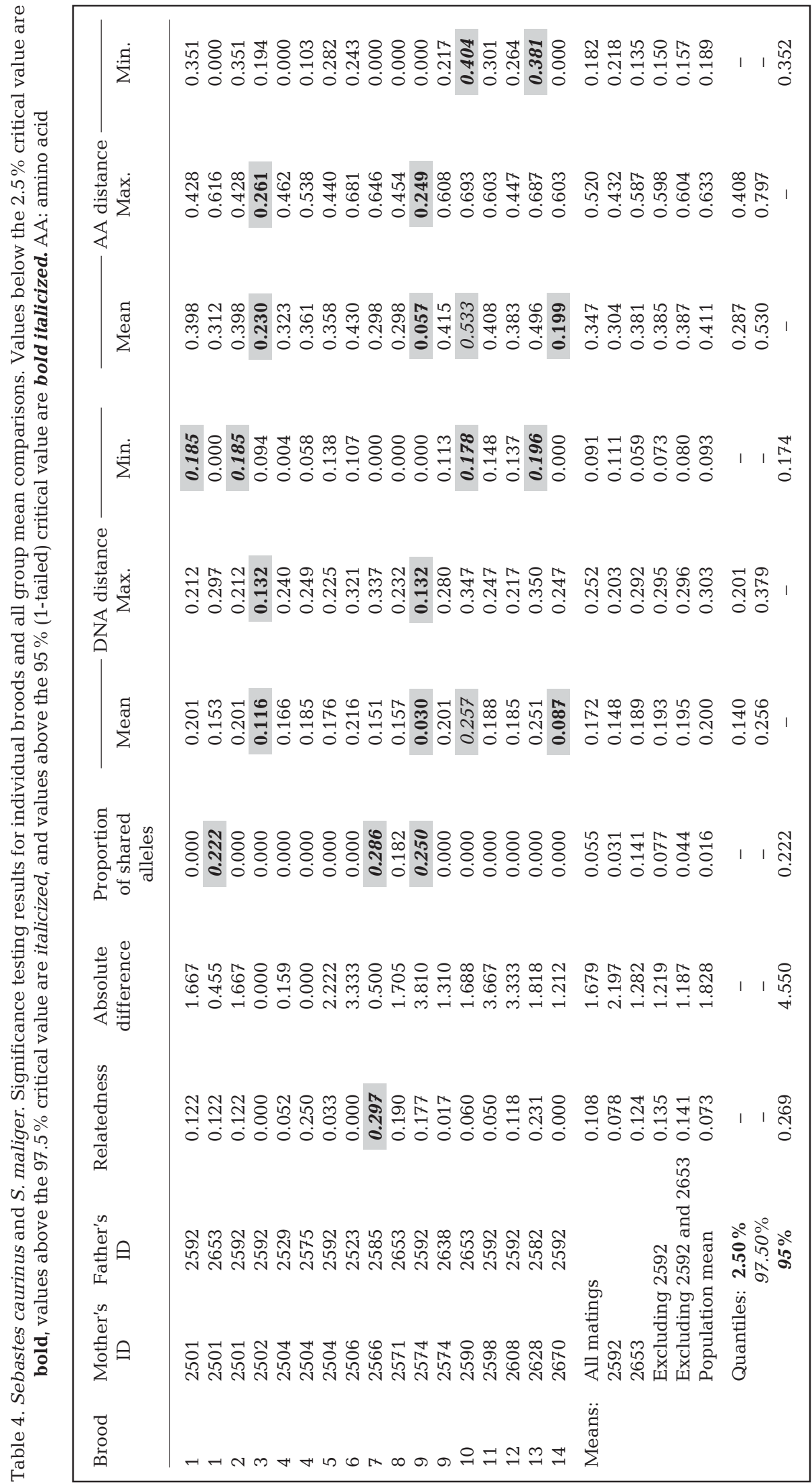


Garza (2005) found between 2 and 7 unique sequences in single individuals of the 12 Sebastes species they considered, including copper rockfish. This compares closely with the average of 5.31 and 5.58 unique sequences per 10 clones sequenced for copper and quillback rockfishes, respectively, in our sample set. Given the high number of alleles per individual in both species, it is likely that sequencing 12 clones per individual underestimates the true intra-individual MHC diversity in both species. However, we believe that this is unlikely to bias our analysis of the role of $\mathrm{MHC}$ in mate selection. It was not possible to assess the paralogous versus allelic status of our different sequences, because intron sequences varied widely in repeat number and thus could not be aligned. Both species were very diverse, both in terms of number of unique sequences, and in genetic distances between sequences. We also found strong evidence of balancing selection, both in ABS and non-ABS codons. This agrees with previous findings, and likely indicates recent functionality of these genes. Our finding of a relatively high degree of trans-species allelism is also in line with previously published findings on MHC in rockfishes (Garrigan \& Hedrick 2003, Aguilar \& Garza 2005).

\section{Parentage analysis}

We found evidence of multiple paternity in 3 of 14 broods examined, all of which were produced by copper rockfish mothers. No evidence of multiple paternity was found in broods from quillback rockfish. Multiple paternity has been described in 13 of 21 rockfish species examined to date (Yoshida et al. 2001, Hyde et al. 2008, Sogard et al. 2008, Van Doornik et al. 2008, Blanco Gonzalez et al. 2009), and seems to be common in the genus. Considering the close relationship of copper and quillback rockfishes (Hyde \& Vetter 2007), the absence of evidence of multiple paternity in quillback rockfish in the present study may be a consequence of low sample size, rather than evidence that it does not occur. Multiple paternity may be a bet-hedging strategy for rockfishes when a female's knowledge of mate selection criteria is imperfect (Yasui 2001). Such a strategy may improve the genetic diversity of offspring from a single female, thereby improving the odds that some fraction of her larvae encounter favorable environmental conditions and survive (Cushing 1990, Hyde et al. 2008, Van Doornik et al. 2008). Another potential benefit of multiple mating for individual females is the potential reduction in the probability of incomplete fertilization of eggs in a brood (Gunderson 1977, Sogard et al. 2008). As a consequence of the benefits to individual females, the population may benefit from reduced inbreeding depression, and an increase in the effective population size ( $N_{\mathrm{E}}$; Hyde et al. 2008). Evidence for hybrid matings was surprisingly common in our data (9 of 14 broods). Although this may be related to effects of long-term holding of parents in captivity, hybridization has previously been described in wild populations of these 2 species (Seeb 1998), and may be a potential source of genetic diversity in the genus Sebastes. Finally, a single male quillback rockfish sired part or all of 8 of the 14 broods in the sample set, and mated with females of both species. Although no previous data exists for mating preferences in rockfishes, results from another study of the related Sebastiscus marmoratus suggest that females may select the largest male available, when direct comparisons are possible ( $\mathrm{Ng}$ et al. 2003). Thus, the dominance of 1 male in our samples may simply result from him being the largest available male. Without matched size and sex data for our samples, however, we can only conjecture.

\section{Mate selection}

Our results suggest that rockfish females pay little attention to overall relatedness when selecting possible mates. We likewise found no evidence for mate selection based on difference in number of MHC alleles. Several pairings shared significantly more alleles than would be expected due to chance, although none of the mating means diverged significantly from null expectations. Similarly, several individual pairings had mean, maximum, or minimum AA or DNA distances that fell outside the critical values. Significant mean and maximum DNA and AA distance values mostly fell below the lower critical value, although 1 mating had mean DNA and AA distances that exceeded the upper critical value. Four matings had significantly or near-significantly greater minimum DNA and AA distances than would be expected due to chance. None of the combined means fell outside the critical values of any of the measured parameters. Significant mean and maximum distances tended to fall below the lower critical value. However, a number of minimum distances fell above the critical value, suggesting that females may prefer males that are moderately divergent in their MHC genotype. Our results are 
consistent with previous findings in sticklebacks that females choose mates with intermediate MHC diversity (Lenz et al. 2009), in this case with respect to genetic distances. However, the overall pattern in our data is of random mating with respect to relatedness and MHC genotype.

\section{CONCLUSIONS}

Rockfishes are characterized by low overall survivorship through the larval stage, coupled with a very high degree of stochasticity in larval survival between years (Love et al. 2002). In most years, few young fish may survive to recruit to the adult population, and strong year classes may only occur once in a decade (Love et al. 2002, Tolimieri \& Levin 2005). The importance of chance in deciding early survivorship may severely discount the importance of selecting mates to specifically optimize larval MHC genotype. Our research suggests that some females may use MHC genotype information to choose mates, but that there is no consistent pattern of preference in the study population. Instead, evidence from the current study suggests that females select mates based on some other measure of quality, such as size, as has previously been shown in the sister genus to Sebastes, the genus Sebastiscus (Ng et al. 2003). In addition, some females mated with multiple males, potentially to avoid unfertilized eggs, or as a bethedging strategy when males displayed similar quality measures (Yasui 2001). The current research strongly suggests that female copper and quillback rockfishes are selective about which males they allow to mate. However, further research will be required to properly isolate the male characteristics that the females use to assess quality.

Acknowledgements. The authors gratefully acknowledge all those who assisted in sample collection and PIT-tagging: E. Mochon-Collura, B. Brady, Z. Steele, R. Hildebrand, D. Wyatt, O. Jaff, J. Fischer, B. Johnson, M. Akers, P. Rankin, T. Frierson, I. Chun, S. Clausen, K. Ravenscroft-Ligman, V. Hodges, J. Burke, and countless Oregon Coast Aquarium volunteer divers. We thank F. Alberto for assistance with data analysis, and S. Heppell, S. Palumbi, V. Buonaccorsi, and 3 anonymous reviewers for comments that greatly improved the manuscript. This work was partially funded by the National Science Foundation REU Site program under Grant No. NSF OCE-0648515.

\section{LITERATURE CITED}

Aeschlimann PB, Haberli MA, Reusch TBH, Boehm T, Milinski M (2003) Female sticklebacks Gasterosteus aculeatus use self-reference to optimize MHC allele number during mate selection. Behav Ecol Sociobiol 54:119-126

Aguilar A, Garza JC (2005) Analysis of major histocompatibility complex class II Beta genes from rockfishes (genus Sebastes). J Fish Biol 67:1021-1028

Belkhir K, Borsa P, Chikhi L, Raufaste N, Bonhomme F (2004) Genetix 4.05, Windows program for population genetics. Available at www.University-montp2.fr/ genetix /genetix.htm

Blanco Gonzalez E, Murakami T, Teshima Y, Yoshioka K, Jeong DS, Umino T (2009) Paternity testing of wild black rockfish Sebastes inermis (brownish type) from the Seto Inland Sea of Japan. Ichthyol Res 56:87-91

Boehlert GW, Yoklavich MM (1984) Reproduction, embryonic energetics, and the maternal-fetal relationship in the viviparous genus Sebastes (Pisces, Scorpaenidae). Biol Bull (Woods Hole) 167:354-370

Brown JH, Jardetzky T, Saper MA, Samraoui B, Bjorkman PJ, Wiley DC (1988) A hypothetical model of the foreign antigen-binding site of class-II histocompatibility molecules. Nature 332:845-850

Brown JH, Jardetzky TS, Gorga JC, Stern LJ, Urban RG, Strominger JL, Wiley DC (1993) 3-Dimensional structure of the human class-II histocompatibility antigen HLADR1. Nature 364:33-39

Casalini M, Agbali M, Reichard M, Konecna M, Bryjova A, Smith C (2009) Male dominance, female mate choice, and intersexual conflict in the rose bitterling (Rhodeus ocellatus). Evolution 63:366-376

Cohen S (2002) Strong positive selection and habitat-specific amino acid substitution patterns in MHC from an estuarine fish under intense pollution stress. Mol Biol Evol 19:1870-1880

Consuegra S, de Leaniz CG (2008) MHC-mediated mate choice increases parasite resistance in salmon. Proc R Soc Lond B Biol Sci 275:1397-1403

> Cushing DH (1990) Plankton production and year-class strength in fish populations - an update of the matchmismatch hypothesis. Adv Mar Biol 26:249-293

Dayhoff MO (1979) Atlas of protein sequence and structure, Vol 5, Suppl 3, 1978. National Biomedical Research Foundation, Washington, DC

> Doherty PC, Zinkernagel RM (1975) Enhanced immunological surveillance in mice heterozygous at $\mathrm{H}-2$ gene complex. Nature 256:50-52

> Eizaguirre C, Yeates SE, Lenz TL, Kalbe M, Milinski M (2009) MHC-based mate choice combines good genes and maintenance of MHC polymorphism. Mol Ecol 18: 3316-3329

> Felsenstein J (1984) Distance methods for inferring phylogenies: a justification. Evolution 38:16-24

Felsenstein J (1989) PHYLIP - Phylogeny inference package (Version 3.2). Cladistics 5:164-166

Forsberg LA, Dannewitz J, Petersson E, Grahn M (2007) Influence of genetic dissimilarity in the reproductive success and mate choice of brown trout-females fishing for optimal MHC dissimilarity. J Evol Biol 20: 1859-1869

Garner SR, Bortoluzzi RN, Heath DD, Neff BD (2010) Sexual conflict inhibits female mate choice for major histocompatibility complex dissimilarity in Chinook salmon. Proc R Soc Lond B Biol Sci 277:885-894

> Garrigan D, Hedrick PW (2003) Perspective: detecting adaptive molecular polymorphism: lessons from the MHC. Evolution 57:1707-1722 
Gingras ML, Ventresca DA, Donnellan MD, Fisher JL (1998) First observations of vermilion rockfish courtship are from a harvest refuge. Calif Fish Game 84:176-179

Gomez-Uchida D, Hoffman EA, Ardren WR, Banks MA (2003) Microsatellite markers for the heavily exploited canary (Sebastes pinniger) and other rockfish species. Mol Ecol Notes 3:387-389

Gunderson DR (1977) Population biology of Pacific Ocean perch, Sebastes alutus, stocks in Washington-Queen Charlotte Sound region, and their response to fishing. Fish Bull 75:369-403

Hallacher LE (1974) The comparative morphology of extrinsic gasbladder musculature in the scorpionfish genus $\mathrm{Se}$ bastes (Pisces: Scorpaenidae). Proc Calif Acad Sci 40: 59-86

Hedgecock D (1994) Does variance in reproductive success limit effective population sizes of marine organisms? In: Beaumont AR (ed) Genetics and evolution of aquatic organisms. Chapman \& Hall, London, p 122-134

> Helvey M (1982) First observations of courtship behavior in rockfish, genus Sebastes. Copeia 1982:763-770

> Hyde JR, Vetter RD (2007) The origin, evolution, and diversification of rockfishes of the genus Sebastes (Cuvier). Mol Phylogenet Evol 44:790-811

> Hyde JR, Kimbrell C, Robertson L, Clifford K, Lynn E, Vetter R (2008) Multiple paternity and maintenance of genetic diversity in the live-bearing rockfishes Sebastes spp. Mar Ecol Prog Ser 357:245-253

Ivanova NV, Dewaard JR, Hebert PDN (2006) An inexpensive, automation-friendly protocol for recovering highquality DNA. Mol Ecol Notes 6:998-1002

> Jones AG (2005) GERUD 2.0: a computer program for the reconstruction of parental genotypes from half-sib progeny arrays with known or unknown parents. Mol Ecol Notes 5:708-711

Kalbe M, Eizaguirre C, Dankert I, Reusch TBH, Sommerfeld RD, Wegner KM, Milinski M (2009) Lifetime reproductive success is maximized with optimal major histocompatibility complex diversity. Proc R Soc Lond B Biol Sci 276:925-934

> Kalinowski ST, Wagner AP, Taper ML (2006) ML-RELATE: a computer program for maximum likelihood estimation of relatedness and relationship. Mol Ecol Notes 6:576-579

Landry C, Garant D, Duchesne P, Bernatchez L (2001) 'Good genes as heterozygosity': the major histocompatibility complex and mate choice in Atlantic salmon (Salmo salar). Proc R Soc Lond B Biol Sci 268:1279-1285

Lea R, McAllister R, Ventresca DA (1999) Biological aspects of the nearshore rockfishes of the genus Sebastes from central California. California Department of Fish and Game. Fish Bull 177:1-109

Lenz TL, Eizaguirre C, Scharsack JP, Kalbe M, Milinski M (2009) Disentangling the role of MHC-dependent 'good genes' and 'compatible genes' in mate-choice decisions of three-spined sticklebacks Gasterosteus aculeatus under semi-natural conditions. J Fish Biol 75:2122-2142

Librado P, Rozas J (2009) DnaSP v5: a software for comprehensive analysis of DNA polymorphism data. Bioinformatics 25:1451-1452

Love MS, Yoklavich M, Thorsteinson L (2002) The rockfishes of the northeast Pacific. University of California Press, Berkeley, CA

Milinski M, Griffiths S, Wegner KM, Reusch TBH, HaasAssenbaum A, Boehm T (2005) Mate choice decisions of stickleback females predictably modified by MHC pep- tide ligands. Proc Natl Acad Sci USA 102:4414-4418

Miller KM, Schulze AD, Withler RE (2000) Characterization of microsatellite loci in Sebastes alutus and their conservation in congeneric rockfish species. Mol Ecol 9: 240-242

Moser H (1967) Reproduction and development of Sebastodes paucispinis and comparisons with other rockfishes off California. Copeia 1967:773-779

Neff BD, Garner SR, Heath JW, Heath D (2008) The MHC and non-random mating in a captive population of Chinook salmon. Heredity 101:175-185

- Ng WC, Sadovy Y, Leung FCC (2003) Mating system of the rockfish, Sebastiscus marmoratus as revealed by DNA fingerprinting. Ichthyol Res 50:339-348

> Penn DJ, Potts WK (1999) The evolution of mating preferences and major histocompatibility complex genes. Am Nat 153:145-164

> Penn DJ, Damjanovich K, Potts WK (2002) MHC heterozygosity confers a selective advantage against multiplestrain infections. Proc Natl Acad Sci USA 99:1126011264

> Ploegh H, Watts C (1998) Antigen recognition-editorial overview. Curr Opin Immunol 10:57-58

R Development Core Team (2011) R: A language and environment for statistical computing. R Foundation for Statistical Computing, Vienna

> Reusch TBH, Haberli MA, Aeschlimann PB, Milinski M (2001) Female sticklebacks count alleles in a strategy of sexual selection explaining MHC polymorphism. Nature 414:300-302

> Roques S, Pallotta D, Sevigny JM, Bernatchez L (1999) Isolation and characterization of polymorphic microsatellite markers in the North Atlantic redfish (Teleostei: Scorpaenidae, genus Sebastes). Mol Ecol 8:685-687

> Seeb LW (1998) Gene flow and introgression within and among three species of rockfishes, Sebastes auriculatus, S. caurinus, and S. maliger. J Hered 89:393-403

> Shinomiya A, Ezaki O (1991) Mating habits of the rockfish Sebastes inermis. Environ Biol Fishes 30:15-22

> Sogard SM, Gilbert-Horvath E, Anderson EC, Fishee R, Berkeley SA, Garza JC (2008) Multiple paternity in viviparous kelp rockfish, Sebastes atrovirens. Environ Biol Fishes 81:7-13

Tolimieri N, Levin PS (2005) The roles of fishing and climate in the population dynamics of bocaccio rockfish. Ecol Appl 15:458-468

- Van Doornik DM, Parker SJ, Millard SR, Berntson EA, Moran P (2008) Multiple paternity is prevalent in Pacific Ocean perch (Sebastes alutus) off the Oregon coast, and is correlated with female size and age. Environ Biol Fishes 83:269-275

Westerman ME, Buonaccorsi VP, Stannard JA, Galver L and others (2005) Cloning and characterization of novel microsatellite DNA markers for the grass rockfish, Sebastes rastrelliger, and cross-species amplification in 10 related Sebastes spp. Mol Ecol Notes 5:74-76

Wetton JH, Carter RE, Parkin DT, Walters D (1987) Demographic study of a wild house sparrow population by DNA fingerprinting. Nature 327:147-149

> Wimberger P, Burr J, Gray A, Lopez A, Bentzen P (1999) Isolation and characterization of twelve microsatellite loci for rockfish (Sebastes). Mar Biotechnol 1:311-315

> Winemiller KO, Rose KA (1992) Patterns of life-history diversification in North American fishes: implications for population regulation. Can J Fish Aquat Sci 49:2196-2218 
Woelfing B, Traulsen A, Milinski M, Boehm T (2009) Does intra-individual major histocompatibility complex diversity keep a golden mean? Philos Trans R Soc Lond B Biol Sci 364:117-128

$>$ Wourms JP (1991) Reproduction and development of Sebastes in the context of the evolution of piscine viviparity. Environ Biol Fishes 30:111-126

Editorial responsibility: Philippe Borsa, Montpellier, France
Yasui Y (2001) Female multiple mating as a genetic bethedging strategy when mate choice criteria are unreliable. Ecol Res 16:605-616

Yoshida K, Nakagawa M, Wada S (2001) Pedigree tracing of a hatchery-reared stock used for aquaculture and stock enhancement based on DNA markers. Fish Genet Breed Sci 30:27-35

Submitted: October 13, 2011; Accepted: May 4, 2012

Proofs received from author(s): July 6, 2012 